
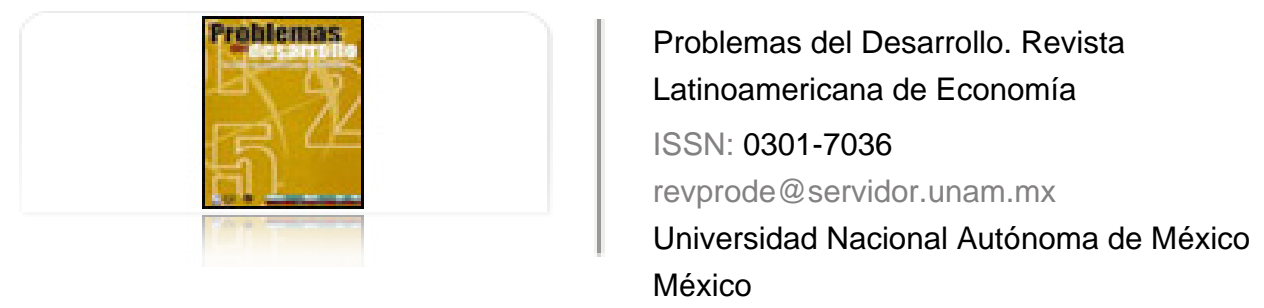

Oladipo, Olajide S.; Vásquez Galán, Belem I.

THE CONTROVERSY ABOUT FOREIGN DIRECT INVESTMENT AS A SOURCE OF GROWTH FOR THE MEXICAN ECONOMY

Problemas del Desarrollo. Revista Latinoamericana de Economía, vol. 40, núm. 158, julio-septiembre, 2009, pp. 91-112

Universidad Nacional Autónoma de México

Distrito Federal, México 


\title{
THE CONTROVERSY ABOUT FOREIGN DIRECT INVESTMENT AS A SOURCE OF GROWTH FOR THE MEXICAN ECONOMY
}

\author{
Olajide S. Oladipo* \\ Belem I. Vásquez Galán**
}

Fecha de recepción: 16 de febrero de 2009. Fecha de aceptación: 16 de junio de 2009.

\begin{abstract}
This paper investigates the ways in which foreign direct investment (FDI) has really affected economic growth in Mexico. Considering that special efforts have been made to rely on an outward industrialisation strategy, we test the FDI-led growth and export-led growth hypotheses in Mexico with multivariate analysis using a Autoregressive Vector model. Results show that support for FDI-led growth is not as strong as for export-led growth. However, NAFTA has been conducive in improving the potential effect of foreign capital inflow. The estimates show that both private and foreign capitals have statistically significant effects on growth. They also show that manufacturing FDI, exports, labour force and human capital have significant positive effects on the economy.
\end{abstract}

Keywords: Foreign Direct Investment, Exports, Growth, Human Capital, NAFTA.

JEL Classification: C32, F21, F43, O1

\section{Resumen}

Este trabajo investiga de qué forma la inversión extranjera directa (IED) ha afectado realmente el crecimiento económico de México. Dado que se han hecho esfuerzos que ponen un énfasis especial en la estrategia de industrialización hacia fuera, ponemos a prueba las hipótesis de crecimiento dirigido por la IED y las exportaciones en México utilizando un modelo multivariado con vectores autorregresivos. Los resultados muestran que la evidencia para el crecimiento dirigido por la IED no es tan fuerte como la evidencia para el crecimiento dirigido por las exportaciones. Sin embargo, el TLCAN ha permitido mejorar los efectos potenciales de los flujos extranjeros. Las estimaciones revelan que el capital privado y extranjero tienen efectos estadísticamente significativos sobre el crecimiento. Las manufacturas, la IED, las exportaciones, el trabajo y el capital humano mostraron efectos positivos sobre la economía.

* Profesor-Investigador, School of Business, Adelphi University.

Correo electrónico: oladipo@ adelphi.edu.

** Profesora-Investigadora, el Colegio de la Frontera Norte. Correo electrónico: belem@ colef.mx 


\section{Résumé}

Ce travail étudie de quelle manière l'investissement étranger direct (IED) a réellement affecté la croissance économique du Mexique. Étant donné que les efforts réalisés mettent nettement l'accent sur la stratégie d'industrialisation vers l'extérieur, il est procédé à la vérification des hypothèses de croissance générée par l'IED et les exportations au Mexique, au moyen d'un modèle multivarié avec vecteurs autorégressifs. Les résultats indiquent que la preuve de croissance générée par la IED n'est pas si évidente que celle de la croissance générée par les exportations. Néanmoins, le TLCAN a permis d'améliorer les effets potentiels des flux étrangers. Selon les estimations, tant le capital privé que le capital étranger ont des effets statistiquement significatifs sur la croissance. Les manufactures, l'IED, les exportations, le travail et le capital humain ont démontré avoir des effets positifs sur l'économie.

Mots clés: Investissement étranger direct, exportations, croissance, capital humain, TLCAN

\section{Resumo}

Este trabalho investiga de que forma o investimento estrangeiro direto (IED) tem afetado realmente o crescimento econômico do México. Dado que têm sido feitos esforços que põem especial ênfase na estratégia de industrialização para o exterior, colocam-se à prova as hipóteses de crescimento dirigido por ied e as exportações no México utilizando um modelo multivariado com vetores autorregresivos. Os resultados mostram que a evidência para o crescimento dirigido por ied não é tão forte como a do crescimento dirigido pelas exportações. No entanto, o tlcan permitiu melhorar os efeitos potenciais dos fluxos estrangeiros. As estimativas mostram que tanto o capital privado como o estrangeiro têm efeitos estatisticamente significativos sobre o crescimento. As manufaturas, os ied, as exportações, o trabalho e o capital humano mostraram efeitos positivos sobre a economia.

Palavras-chave: Investimento estrangeiro direto, exportações, crescimento, capital humano, TLCAN. 


\section{Introduction}

he last two decades have witnessed a tremendous increase in the stock of Foreign Direct Investment (henceforth, FDI) at the global level. In Mexico, the structural reforms introduced after the economic crisis of 1986 and membership of the North America Free Trade Area (NAFTA) in 1994 have made the country one of the most important recepients of FDI inflows in Latin America. According to the World Investment Report 2006 published by the United Nations Conference on Trade and Development (UNCTAD), in 2005, 'Mexico received more than 19 billion U.S dollars which puts it among the top 13 in the world and among the top four in developing countries'. Given this huge inflow into Mexico, the germane questions are: How does inward FDI interact with the host country's economic growth? And has there been any real positive effect?

A number of studies have examined the effects of FDI on growth in developing countries. Balasubramanyam et al. (1991) conducted extensive research work on the nature and determinants of foreign capital and how they affect the economic performance of host developing countries, and this offers some insightful information. They provide evidence that trade policy orientation determines the nature and magnitude of foreign investment. Open economies tend to attract more foreign investment than closed economies that might be experiencing domestic distortions due to protectionism. It was shown that the elasticity of output to foreign capital is stronger in countries with export-oriented policies than in countries with inward-oriented policies, which attests to the assertion that in an open environment, FDI offers more benefits to the host developing country (Balasubramanyam et. al 1996). Greenaway et al. (2007) tested these hypotheses with data from 1990 to 2000 on a larger sample and confirmed that they still hold. Not only that, they also provided information that even within the sample of open economies, the ones with the highest levels of openness were more receptive to foreign capital.

However, findings from the various cross-sectional studies on the relationship between FDI and growth in developing countries cannot be generalized. There is a need for country-specific studies on the subject matter to shed more light on the debate and allow for more country-specific policies. Also, these studies make an a priori presumption that FDI responds to or causes economic growth. But investigation of the causal link between FDI and growth has important implications for development strategies. Causality from FDI to income growth would lend credence to the FDI-led growth hypothesis. If the causal process were in the reverse direction, this would imply that economic growth is a prerequisite for Mexico to attract FDI. In either case, 
the impact of FDI flows will also depend on the country's absorptive capacity. If the causal process is bi-directional, then FDI and growth are interdependent and would therefore have a reinforcing causal relationship.

For the Mexican economy, the impact of aggregate FDI on economic growth remains an open question. In order to avoid the pit-falls of previous studies, this paper aims to first investigate causality between FDI, exports, and economic growth for Mexico based on a theoretical framework and an estimation method that was developed fairly recently. Also, given the huge inflow of FDI into Mexico since the NAFTA agreement in 1994, we examine the effect of FDI on gross domestic product (GDP) growth in Mexico over the period 1970:1-2004:4. These, of course constitute the objectives of this paper. We hypothesize that openness has laid the conditions to attract more foreign capital to Mexico and we, therefore, expect FDI to be not only a positive determinant of output growth but also a mechanism to improve human capital and technology transfer through its spillover effects.

The paper is organized into four sections. Following the introduction, section two contains brief theoretical and empirical issues on the relationship between FDI and economic growth. In section three, we present the estimatione model, while section four provides the estimate results. The last section contains the conclusion and policy recommendations.

\section{Theoretical and empirical issues on FDI and growth}

Theoretical and empirical literature on FDI point to two broad channels through which FDI can improve the production efficiency in the host country -technology transfer, and spillover benefits to domestic firms ${ }^{1}$ (Dimelis, 2005; Li and Liu, 2005; Schneider et al., 2005) The theoretical justifications are straightforward and plausible. Technology transfer by the foreign parent company can occur through the addition of more productive capital stock and the adoption of product and process innovations, and through R\&D and innovation activities of these firms in the host countries. According to new growth theory, spillover affects host economies through changes in the nature of market concentration as well as through training of labor and local staff, improvement in quality and reliability of inputs learned by watching, and increased competition among less efficient domestic firms. Romer (1993) echoed

1 Evidence of this is provided in the works of Balasubramanyam et al. (1996) and Borensztein et al. (1998). 
the 'idea gap' between rich and poor countries and asserts that FDI can improve the ease of technology transfer and know-how to poor countries with possible substantial spillover effects. In general, foreign financing is considered an important engine of economic growth as it helps cover the gap between actual investment in the economy and the investment needed to sustain economic growth.

However, as articulated by Buckley et al. (2002) and De Mello (1999), the extent to which FDI contributes to growth depends on the economic and social conditions, and the environmental quality of the host country ${ }^{2}$. The quality of the environment relates to savings and financial development in the host country, the degree of trade openness, human capital development and the level of technological development. Ceteris paribus, economies with high savings, trade openness and high technological product tend to attract more FDI and benefit from it.

Empirical evidence has established a robust link between FDI and economic growth in host countries. From cross-country studies such as De Mello (1997) for five Latin American countries (Brazil, Mexico, Venezuela, Chile and Colombia) evidence abounds that FDI has a positive impact on growth in open economies. Balasubramanyam et al (1996) showed that trade openness was crucial for obtaining the growth-effects of FDI in a cross-section of 46 developing countries. Blomstrom et al. (1994a) found that FDI had a positive impact on the growth of GDP in more advanced developing countries for the period 1970-1989. Also, it confirmed that openness and macroeconomic stability were strong incentives for foreign investment. Another important determinant of FDI found by Boreszstein et al. (1998) is the existence of a minimum threshold stock of human capital in the host country. They found that only then is FDI an important vehicle for technology transfer and contributes relatively more to growth than domestic investment.

Specifically, foreign firms may help developing country firms enter world markets by providing links to final buyers outside their own country. Using firm level data from Indonesia, Sjoholm (1999) finds that FDI does benefit locally owned firms, -though the benefits differ between groups of industries -with larger technology gaps having bigger spillover effects for domestic producers. Zhao (1995) shows that for China, in addition to output growth, indigenous technological capability is positively affected by technological imports.

2 Also, FDI may have negative effect on the growth prospects of the recipient economy if it gives rise to substantial reverse flows in the form of profit remittances and dividends and if the transnational corporations obtain concessions from the host country. 
For Bromstrom and Kokko (1998) the evidence suggests that the positive technological effects of MNCs are likely to improve in the presence of competition and local capability. MNCs react strongly (and therefore increase technological transfers) in the presence of domestic competition that forces them to maintain their leading position. In the same fashion, Bromstrom et al. (1994b) found that skilled labour, local competition and growth in the Mexican manufacturing industries were positive determinants of technology transfers by foreign plants. Meanwhile, Love and LageHidalgo (2000) found that FDI from the US was positively determined by domestic demand and the differences in relative wages. This supports the position that cheap labour is still an important incentive to invest in Mexico. Blomstrom and Persson (1983) employed data for 2154 -digit Mexican industries for 1970. They relate labour productivity to measures of capital intensity, labour quality, economies of scale, extent of foreign penetration, and the degree of competition. Their study provides strong support for the existence of FDI-related spillovers.

Marwah and Klein (1996), in the case of India, employed transcendental and CES generalization of Cobb-Douglas production functions with four different inputs. They showed that 0.7 percent of every 1 percent of economic growth was attributed to the growth of foreign capital. For China, Sun (1998) employed a log-linear production function and found that a 1 percent increase in FDI led to a 0.05 percent growth of GDP. In general and other things being equal, open economies are expected to have higher causal relationships from FDI to growth.

Fluctuations of the exchange rate have also been found to be a relevant determinant of foreign investment inflows and export growth. Real depreciation of the local currency is usually considered an incentive to take advantage of relatively cheap labour and input costs, although it also affects the composition of FDI. For example in the case of Mexico, in periods of real depreciation of the exchange rate, 1982 to 1990 and 1995 to 1999, FDI in manufactures was higher than in other economic sectors. Considering that most of the manufactures are export goods, a real depreciation has a positive effect on the current account. On the other hand, a real appreciation of the exchange rate tends to divert FDI from manufactures to other sectors where there is a high share of non tradable goods (retailing and services). This happened between 1991 and 1994 and between 2000 and 2005 (Ros, 2008). In other words, sub valuation reduces exports but has the positive effect of diverting financial resources for the internal market.

Comparison of the likely positive effects of public and private investment on growth seems to reveal that private investment stimulates growth more than public investment. 
Recently, Aka (2007) examines the importance of public and private spending on the FDI-led growth debate. Using an autoregressive-distributed lag (ARDL) Error Correction Model (ECM) on annual data from 1969 to 2001, he confirmed that an increase in private investment by 1 percent enhances economic growth by 28 percent, while a 1 percent increase in public investment leads to only a 7 percent increase in real GDP for Cote d'lvoire. The international experience, as surveyed in a multicountry study by Easterly, Rodriguez and Schmidt-Hebbel (1994), suggests that it is far more common for public investment to crowd out than to crowd in private investment. The conventional wisdom that public investment is good for private investment is contradicted by the evidence in half of the case studies, where public investment has a negative and statistically significant effect on private investment. The negative association in some cases is explained by the likelihood that public investment is replacing rather than complementing private investment. Concentration of public infrastructure investment and on the privatization of other state enterprises would ensure a complementary relationship between the public and private sectors. According to Lachler and Aschauer (1998) the time-series regression results for Mexico all point toward a crowding out coefficient of less than unity. Thus, its existence limits the growth impact of public investment by reducing its net effect on capital accumulation. However, they state that increases in public investment have a positive net impact on economic growth, despite significant crowding out effects.

Further, Khan and Kumar (2001) extended the basic neoclassical model of growth by separating investment into its public and private components and estimated the model for a sample of 95 developing countries. Their results suggest that once other determinants of growth, such as human capital formation, population growth, and technical progress are taken into account, public and private investment have different effects on growth, and that these effects are characterized by marked regional and inter-temporal variations. Nunnenkamp and Bremont (2007) investigate the relationship between FDI and employment generation in Mexico using a panel time data series from 1994 to 2006. Employing the GMM estimator, their findings suggest that FDI has a significantly positive, though quantitatively modest impact on manufacturing employment in Mexico. They found no evidence supporting the widely held view that FDI adds to white collar employment in the first place. However, the positive effect on blue collar employment diminishes with the increasing skill intensity of manufacturing industries.

Some empirical findings suggest a positive relationship between FDI and economic growth. However, a number of studies present pessimistic evidence for the 
growth effect of FDI. The firm level studies of particular countries often claim that FDI does not boost economic growth, Carkovic and Levine (2002). These studies cast doubts on the true existence of positive spillovers from foreign to domestic owned firms. Aitken and Harrison (1999) for example, found no evidence of positive technology transfer spillover from foreign-owned to domestic-owned firms in Venezuela between 1979 and 1989. Likewise, Haddad and Harrison (1993), in their study of Morocco over the period of 1985 through 1989, discovered a negative spillover from foreign presence to the productivity growth of domestic firms, but it was not statistically significant.

Empirical studies have so far not offered a clear-cut conclusion with respect to the causality between FDI and growth. The surge of FDI might be associated with domestic policy variables, and this was evidenced in the case of Latin America (Elias, 1992). De Mello (1997) finds that FDI played a determinant role in increasing both output and total factor productivity (TFP) in Chile, while capital accumulation and TFP growth preceded FDI in Brazil. In both cases the direction of the relevant causalities cannot be determined. The direction of causality between FDI and growth may well depend on the determinants of FDI. If the determinants have strong links with growth in the host country, growth may be found to cause FDI, while output may grow faster when FDI takes place under other circumstances.

Stylized facts about FDI in Mexico show that foreign and partially foreign owned companies increased their share in total exports from 14.3 percent in 1993 to 19.1 percent in 1998. It seems that NAFTA improved the conditions for attracting foreign capital, and considering that most of these companies are exporters, it meant that more goods were sold in the international market. However, in terms of employment, foreign companies have not had a strong positive effect. From 1993 to 1998 on average their share on total job creation was 3.4 percent. In absolute terms it meant they hardly created 822000 jobs out of the 8.5 millions created by the rest of the economic sector (Dussel, 2000a).

One of the goals in joining NAFTA was the idea that exports and FDI would induce rapid growth rates in Mexico, but in the post-NAFTA period most of the export industry has created few linkages with domestic intermediary producers. For example, the non-maquiladora manufacturing sector actually reduced its domestic content from 91 percent in 1983 to 37 percent in 1996. Meanwhile maquiladoras have maintained an average domestic content of 2 to 3 percent (Arroyo, 2003). These results are a consequence of rules of origin that require producers to include only some percentage of regional content instead of domestic content as a requirement. Better terms for compe- 
tition under NAFTA could have been an important instrument to stimulate linkages with intermediary producers in the less developed country, in this case Mexico. In addition to this, in terms of FDI, reforms on foreign investment regulations have caused the potential benefits for the host economy to deteriorate. The Law of Foreign Investment from 1996 removed all the requirements that the Law from 1989 had stipulated, for example maintaining a positive balance of foreign exchange during the first three years and creating jobs, among other things (Dussel, 2000a).

\section{Econometric Modeling}

In order to examine the importance of FDI on growth for the Mexican economy, we specify a production function in which FDI is explicitly incorporated as a factor of production. This is synonymous with the sources of growth equation derived from the

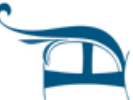
neoclassical production function ${ }^{3}$ :

$$
\mathrm{Y}_{t}=\left[(\lambda L), K_{p}, \mu\right]=\mathrm{A}_{t}(\lambda L)^{\alpha} K_{t}^{\beta}, \mu^{1-\alpha-\beta} \quad \text { where } \lambda=H^{Z}
$$

$\mathrm{Y}_{t}$ is the real output, $K_{p}$ is private capital stock (proxied in the usual way by the share of investment in output), $L$ is raw labor input, $\lambda$ is the level of human capital, $H$ is a measure of the educational level, ${ }^{Z}$ is the return to education relative to raw labor input, $A$ is the efficiency of production, $\mu$ is the externality generated by additional FDI stock, and $\alpha$ and $\beta$ are the private capital and labor shares, respectively. It is assumed that $\alpha$ and $\beta$ are less than one, such that there are diminishing returns to the labor and capital inputs. The externality $\mu$ is represented by a Cobb-Douglas production function of the form:

$$
\mu=\left[(\lambda L), K_{p}, K_{f}^{\sigma}\right]^{\gamma}
$$

where $\sigma$ and $\gamma$ are, respectively marginal and the intertemporal elasticities of substitution between private and foreign capital. Let $\sigma>0$, such that a larger stock of FDI yields a positive externality to the economy. If $\gamma>0$, intertemporal complementarity

3 This methodology is based on previous work developed by De Mello (1997), Ramirez (2000) and Akinlo (2004). However, unlike most previous studies that used only raw labor, we introduced human capital into our model to ascertain its impact on growth. This was included because in most cases FDI requires high level manpower to work with in a host country. 
prevails and, if $\gamma<0$, additions to the FDI stock crowd out private capital over time and diminish the growth potential of the host country.

Thus, we combine equations 1 and 2 to obtain:

$$
Y_{t}=A_{t}(\lambda L)^{\alpha} K_{p}^{\beta}\left[\left\{(\lambda L), K_{f}, K_{f}^{\sigma}\right\}_{\gamma}\right]^{1-\alpha-\beta}
$$

When equation 3 is factored, we have;

$$
Y_{t}=A_{t}(\lambda L)^{\alpha+\gamma(1-\alpha-\beta)} K_{p}^{\beta+\gamma(1-\alpha-\beta)} K_{f}^{\sigma \gamma(1-\alpha-\beta)}
$$

Substituting $\lambda=H^{Z}$ and taking logarithms and time derivatives of equation 5, we generate the following dynamic production function:

$$
\begin{gathered}
\psi_{y}=\psi_{A}+z[\alpha+\gamma(1-\alpha-\beta)] \psi_{H}+[\alpha+\gamma(1-\alpha-\beta)] \psi_{L}+ \\
{[\beta+\gamma(1-\alpha-\beta)] \psi_{K_{p}}+[\sigma \gamma(1-\alpha-\beta)] \psi_{K_{f}}}
\end{gathered}
$$

where $\psi$ is the growth rate of $i=Y, L, H, K_{p}$ and $K_{f}$. Equation 6 implies that given $\sigma$ and $\gamma>0$ and $z$ is also positive, additions to stock of FDI will augment the elasticities of output with respect to raw labor, capital and human capital by factor $\gamma(1-\alpha-\beta)$.

Hence, derived from equation 6 above, the equation estimated in our case takes the form:

$$
\begin{gathered}
\Delta y=d_{0}+d_{1} \Delta l+d_{2} k_{p}+d_{3} \Delta k_{f}-d_{4} \Delta h+d_{5} \Delta x+ \\
d_{6} \Delta c_{g}+c_{7} \Delta B_{g}+c_{8} \Delta F_{n}+d_{9} D+c_{10} T+\varepsilon
\end{gathered}
$$

In equation 6 , the lower case denotes natural logarithms, and $\Delta$ is the difference operator; $y$ is the natural $\log$ of real GDP, $l$ is the labor, $K_{p}$ and $K_{f}$ are the stocks of private and foreign capital respectively; $C_{g}$ is real government consumption, $x$ is real exports, $h$ is human capital proxied by the share of students in secondary school in the population, $D$ is an adjustment dummy variable, 1 for adjustment period 1986 to 2004 and 0 otherwise, $F_{n}$ stands for the financial depth measure as a ratio of money supply broadly defined to GDP, $B_{g}$ is budget balance over GDP. $T$ is the time trend to capture secular trend in output during the period of study.

While equation (6) captures the impact of important variables on GDP growth, it does not account for the possibility of a bi-directional relationship between growth and 
FDI highlighted in the literature. To capture these temporal causality relationships, the technique of Granger causality is employed. The test involves estimating the following regressions:

$$
\begin{gathered}
y_{t}=a_{0}+\sum_{j=1}^{p} a_{j} y_{t-j}+\sum_{j=1}^{p} b_{j} K_{f, t-j}+\mu_{t} \\
K_{f t}=m_{0}+\sum_{j=1}^{p} m_{j} K_{f, t-j}+\sum_{j=1}^{p} e_{j} y_{t-j}+v_{t} \\
y_{t}=z_{0}+\sum_{j=1}^{p} z_{j} y_{t-j}+\sum_{j=1}^{p} \eta_{j} x_{t-j}+\mu_{1 t} \\
x_{t}=r_{0}+\sum_{j=1}^{p} r_{j} x_{t-j}+\sum_{j=1}^{p} s_{j} y_{t-j}+\omega_{t}
\end{gathered}
$$

where $y_{t}, K_{f}$ and $x_{t}$ are stationary time-series, $\mu_{t}, v_{t}, \omega_{t}$ and $\mu_{1 t}$ are uncorrelated error terms and $p$ is the lag order selection. However, if there exists co-integration between FDI and GDP, and exports and GDP, the appropriate format is to investigate the long run causality in the error correction model (ECM). From equation ( 7$), K_{f}$ (FDI) Granger causes $y$ (GDP) if $b_{j} \neq 0$. Also, equation (8) shows that $y$ Granger causes $K_{f}$ if $e_{j} \neq 0$. From equation (9) $x$ (exports) Granger causes $y$ (GDP) if $\eta_{j} \neq 0$, while in equation (10) $y$ (GDP) Granger causes $x$ (GDP) if $s_{j} \neq 0$. Bi-directional Granger causality is obtained if $b_{j} \neq 0, e_{j} \neq 0, \eta_{j} \neq 0$ and $s_{j} \neq 0$. We employed time-series data from 1970:1 to $2004: 4$ to estimate equations (6), (7), (8), (9), and (10). We employed time-series data from 1970:1 to 2004:4 to estimate equations (6), (7), (8), (9), and (10). The data were compiled from statistics published by El Banco de México, El Instituto Nacional de Estadistica, Geografia e Informatica (INEGI), International Financial Statistics from the International Monetary Funds and the World Bank (see appendix for details).

\section{Empirical results}

The finding that most macroeconomic time-series data may contain a unit root has spurred the development of the theory of non-stationary time-series analysis. Thus, to make valid statistical inferences and meaningful policy analysis, it is germane to address the time-series properties of all the variables used to avoid the problems of spurious relationships and invalid inferences. Testing is normally extended to account for a deterministic trend as well as the stochastic type of trend represented by a unit root. A number of tests can be found in the literature -we choose Dickey and Fuller 
(1981) and Phillips and Perron (1988). Thus, our data is tested for unit root by the Augmented Dickey Fuller (ADF) and Phillip-Perron (PP) tests with a constant and a deterministic trend. Both tests are applied so that modelling directions are not inclined toward accepting one type of trend over the other. The results of the ADF tests are presented in Table 1 below 4 .

Table 1

Results of the ADF Tests

\begin{tabular}{|c|c|c|c|c|c|}
\hline & Variable & Levels & First difference & Critical value (5\%) & Critical value (1\%) \\
\hline \multirow{9}{*}{$\begin{array}{l}\text { Panel (A): Mexico: unit root tests for } \\
\text { stationarity with constant and time } \\
\text { trend, sample period 1970-2004 }\end{array}$} & $y$ & -3.34 & $-5.52^{\star}$ & -3.46 & -4.06 \\
\hline & $k_{p}$ & -2.54 & $-4.39 *$ & -3.46 & -4.06 \\
\hline & $k_{f}$ & -2.1 & $-7.96^{*}$ & -3.46 & -4.06 \\
\hline & $x$ & 0.39 & $-6.14^{\star}$ & -3.46 & -4.06 \\
\hline & 1 & -2.39 & $-3.77^{\star \star *}$ & -3.46 & -4.06 \\
\hline & $h$ & -2.94 & $-3.53^{\star \star}$ & -3.46 & -4.06 \\
\hline & $b_{g}$ & -2.03 & $-10.87^{\star}$ & -3.46 & -4.06 \\
\hline & $f_{n}$ & -2.95 & $-4.11^{\star}$ & -3.46 & -4.06 \\
\hline & $c_{g}$ & -3.15 & $-10.41^{\star}$ & -3.46 & -4.06 \\
\hline \multirow{9}{*}{$\begin{array}{l}\text { Panel (B): Mexico: unit root tests for } \\
\text { stationarity with constant only, } \\
\text { sample period 1970-2004 }\end{array}$} & y & 0.94 & $-5.30^{\star}$ & -2.89 & -3.5 \\
\hline & $k_{p}$ & -1.17 & $-5.48^{\star}$ & -2.89 & -3.5 \\
\hline & $k_{f}$ & 0.81 & $-7.89^{\star}$ & -2.89 & -3.5 \\
\hline & $x$ & -2.2 & $-9.34^{\star}$ & -2.89 & -3.5 \\
\hline & 1 & -0.8 & $-3.78^{\star}$ & -2.89 & -3.5 \\
\hline & $h$ & 0.41 & $-2.94^{\star \star}$ & -2.89 & -3.5 \\
\hline & $b_{g}$ & -1.25 & $-10.9^{\star}$ & -2.89 & -3.5 \\
\hline & $f_{n}$ & -1.85 & $-3.11^{\star \star}$ & -2.89 & -3.5 \\
\hline & $c_{g}$ & -2.18 & $-10.28^{\star}$ & -2.89 & -3.5 \\
\hline
\end{tabular}

Notes: Mackinnon (1996) critical values for rejection of hypothesis of a unit root

* Denotes significance at $1 \%$ level

** Denotes significance at $5 \%$ level

$\alpha$ Variable stationary at the $10 \%$ level

The results in Table 1 revealed that all the variables are integrated for order one $I(1)$. Therefore, having established that the series are $I(1)$, we employed the JohansenJuselius (1990) technique to test for co-integration.

4 Similar results were obtained when we employed the Phillip-Perron approach. 
Table 2

Results Co-integration Results (with a linear trend) where $\Gamma$ is the number of Co-integrating Vectors ${ }^{5}$

\begin{tabular}{|c|c|c|c|c|c|c|}
\hline & Null & Alternative $\Gamma$ & $\lambda_{\max }$ & Critical value (95\%) & Trace & Critical value (95\%) \\
\hline \multirow{5}{*}{$\begin{array}{l}\text { Panel (A): Estimates of } \lambda \\
\text { max and trace tests }\end{array}$} & 0 & 1 & 34.37 & 3.46 & 80.27 & 68.52 \\
\hline & $\leq 1$ & 2 & 19.09 & 27.07 & 45.9 & 7.21 \\
\hline & $\leq 2$ & 3 & 17.34 & 20.97 & 26.8 & 9.68 \\
\hline & $\leq 3$ & 4 & 9.31 & 14.07 & 9.46 & 5.41 \\
\hline & $\leq 4$ & 5 & 0.15 & 3.76 & 0.15 & 3.76 \\
\hline Panel (B): Estimates of & $y$ & 1 & $h$ & $k_{p}$ & $k_{f}$ & \\
\hline co-integrating vector & 1.00 & $-0.97(-5.31)$ & $-0.51(-8.32)$ & $-0.41(-2.07)$ & $-0.61(-5.44)$ & \\
\hline
\end{tabular}

Panel A of Table 2 reports both the trace and maximum eigenvalue statistics for co-integration tests. Our results revealed that the null hypothesis of no co-integration can be rejected using the $\lambda$-max or the trace statistics. They are both greater than their critical values at a $5 \%$ level of significance. This indicates that there exists a unique co-integrating vector among the variables involved. The co-integrating equation normalised on the growth variable as reported in panel B of Table 2 revealed that raw labour, private capital, foreign capital and human capital are positive (the signs are reversed because of the normalization process). The coefficients are all significant as shown by the t-ratio indicated in parentheses.

Since the existence of co-integration among these variables is confirmed, the next step is to test the causal relationships among FDI flows, openness through trade, and GDP growth with an Error Correction Mechanism (ECM) model. The literature offers different statistical methods to determine the optimal lags in Granger causality tests. The Schwarz and Bayesian Criterion (SBC) and the Akaike Information Criterion (AIC) are used to determine the optimal lag lengths in the ARDL and error correction models (Hsiao, 1981). The causal directions are detected by $F$-statistics and the signs of the causal effects are determined by adding the coefficients on lagged independent variables.

We first test if $K_{f}$ (FDI) Granger causes $y$ (GDP) by estimating the unrestricted equation (7), and restricted equation (7) by dropping lagged $K_{f}$. The $F$ statistic yields

5 The reported results here are without a constant, although when a constant is introduced the results obtained are not significantly different. 
value of $11.157^{6}$ which exceeds the critical values of $F_{0.01}=5.53$. Thus, we can reject the null hypothesis $\left(b_{j}=0\right)$ and conclude that adding lagged values of $K_{f}$ does improve the statistical results. This implies that FDI Granger causes GDP growth, thus providing evidence for FDI-led growth hypothesis. In other words, the GDP growth rate improves with the inclusion of past changes in FDI. The same procedure was carried out with respect to equations (8), (9), and (10). The results from equation (8) indicate that Granger GDP growth does not cause FDI in Mexico ( $F$ statistic 4.11, below the critical value of $F_{0.01}=5.53$ ) which implies a unidirectional relationship between GDP and FDI.

Our results from equations (9) and (10) suggest that Granger exports cause GDP growth, however, GDP growth does not cause Granger exports. These results provide evidence that exports play a relevant role in explaining economic expansion and also support the export-led hypothesis. The results also suggest that liberalization in Mexico has had a significant impact on the economy thanks to higher levels of exports due to a more flexible trade policy. Furthermore, our results revealed that Granger exports cause FDI ( $F$ statistic 8.71, is higher than the critical value of $F_{0.01}=5.53$ ), although FDI does not cause exports.

Given the importance of NAFTA as a regional agreement with Mexico's most important trade partners (Canada and the USA), and the expectation that there might have been a structural change due to this treaty which might have altered the way in which exports and FDI interact with the economy ${ }^{7}$, as an additional exercise we split the sample into two sub-periods: from 1970:1 to 1993:4, which are the years before NAFTA, and from 1994:1 to 2004:4 when NAFTA became effective, and then tested the hypothesis of a structural change. We followed the same procedure used for the selection of the lag structure and found that an unrestricted VAR with 4 lags satisfied the diagnostic tests ${ }^{8}$. The results obtained show that positive changes in the stock of FDI did cause Granger output growth.

6 The F statistic can be calculated using $\frac{\left(R S S_{R}-R S S_{U R-} / m\right)}{R S S_{L R} / n-k}$ where in the present case is equal to the number of lagged terms and is the number of parameters estimated in the unrestricted regression.

7 Similar influences of such regional agreement have been reported by Vamvakidis (1999) for the European Free Trade Agreement (EFTA) between Norway, Switzerland and Iceland; the South Pacific Regional Trade and Economic Cooperation Agreement (SPARTECA) between Australia, Fiji, New Zealand, Papua New Guinea, the Solomons Islands, Tonga and Western Samoa; and the Southern African Development Community (SADC) between Angola, Botswana, Congo, Botswana, Mauritius, Mozambique, Namibia, South Africa, Tanzania, Zambia, Zimbabwe.

8 Results available upon request. 
This is an indication that Mexico had strategic advantages before NAFTA (for example, low labour costs, geographical location, and other trade agreements).

The results show some interesting aspects of the influence of NAFTA on the Mexican economy. It was only after NAFTA's entry that output growth had a positive effect on FDI and was statistically significant $(F$ statistic $=12.01$ is higher than the critical value of $F_{0.01}=5.53$ ). Output growth could be an indication of macroeconomic stability and economic progress, which constitute some attraction for FDI into Mexico. Before NAFTA, GDP did not cause Granger exports and FDI did not cause exports, but only when the effect of NAFTA is considered does that GDP causes exports and FDI causes exports. This provides evidence that more international integration was conducive to improved foreign capital flows to Mexico. It is interesting to note that the economic performance and the existence of an export market seem to be explicative of positive

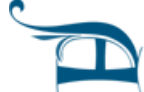
changes in FDI.

Table 3 presents the results of the estimated equation 6 in which the growth of GDP is generated by growth in domestic investment, FDI, exports, government expenditure, financial depth as well as the level of human capital. In regressions 3.1 to 3.6 various interactive terms are added into the equation to examine their effect on growth in Mexico. Therefore, Table 3 reveals several interesting results concerning the effects of FDI on economic growth.

Regressions 3.1 to 3.6 indicate that FDI has a positive impact on economic growth, which confirms our hypothesis of FDI as an important source for economic of growth. This is not surprising because trade and investment flows into Mexico have increased with the United States as the major trading partner since the government introduced outward-oriented strategies in the 1980s. Also, the acceleration of international trade and investment might not be unconnected with the legal reforms introduced in the years prior to NAFTA that relaxed regulations on the property of foreigners in Mexico ${ }^{9}$.

9 In 1993, the Law of Foreign Investment was reformed to allow higher shares of foreign capital in economic activity, see Diario Oficial de la Federación. 
Table 3 Mexico Error Correction Model (dependent Variable $\Delta \ln Y t$ )

\begin{tabular}{|l|c|c|c|c|c|c|}
\hline Variables & 3.1 & 3.2 & 3.3 & 3.4 & 3.5 & 3.6 \\
\hline Constant & $0.31(2.54)$ & $0.32(1.97)$ & $0.36(3.17)$ & $0.36(3.97)$ & $0.38(2.95)$ & $0.39(3.15)$ \\
$\Delta \ln l_{t}$ & $0.17(3.42)$ & $0.19(3.62)$ & $0.12(1.89)$ & $0.08(2.36)$ & $0.15(2.98)$ & $0.43(3.33)$ \\
$\Delta \ln h_{t}$ & $0.08(2.37)$ & $0.07(2.16)$ & $0.06(2.19)$ & $0.23(2.04)$ & $0.004(2.29)$ & $0.14(2.87)$ \\
$\Delta \ln k_{t}$ & $0.38(2.86)$ & $0.23(3.29)$ & $0.17(1.97)$ & & & \\
$\Delta \ln k_{t}$ & $0.21(3.21)$ & $0.16(3.07)$ & $0.12(2.02)$ & $0.15(2.78)$ & $0.13(2.21)$ & $0.18(2.11)$ \\
$\Delta \ln x$ & $0.17(2.84)$ & $0.18(6.04)$ & $0.14(2.08)$ & & $0.30(6.19)$ & $0.19(2.37)$ \\
$\Delta \ln c_{g t}$ & & & & $0.25(2.23)$ & $0.27(2.01)$ & $0.29(2.03)$ \\
$\Delta \ln f_{n}$ & $0.01(1.96)$ & $0.09(1.89)$ & & $0.05(3.79)$ & $0.04(2.31)$ & $0.15(3.54)$ \\
$D$ & $0.009(4.72)$ & & & & $0.008(2.45)$ & $0.005(3.02)$ \\
$\Delta B g$ & & & & $0.04(4.01)$ & $0.06(2.67)$ & $0.01(4.20)$ \\
$I$ & $0.01(2.08)$ & $0.02(3.92)$ & & $0.007(3.78)$ & $0.008(3.51)$ & $0.004(2.29)$ \\
$E C M_{t-1}$ & $-0.24(-3.64)$ & $-0.25(-2.10)$ & $-0.29(-3.87)$ & $-0.30(-4.72)$ & $-0.31(-3.40)$ & $-0.34(-4.19)$ \\
$R=2$ & 0.72 & 0.64 & 0.6 & 0.59 & 0.67 & 0.66 \\
$S . E$ & 0.009 & 0.008 & 0.004 & 0.007 & 0.007 & 0.007 \\
$D . W$ & 1.96 & 1.97 & 2.01 & 2.04 & 2.04 & 2.05 \\
$A R(1)$ & 0.42 & 0.34 & 0.27 & 0.38 & 0.32 & 0.35 \\
\hline
\end{tabular}

Note: all variables are as defined earlier and F- statistic in parenthesis

We observed in regressions 3.1, 3.2 and 3.6 that the addition to growth rates of exports does not reduce, but rather increases, the significance of the FDI variable. It has been observed not only for Mexico but for other countries that once they become part of a regional trade agreement, FDI inflows to those countries increase considerably ${ }^{10}$. The reason may be that most of this sort of investment engages in export activities in host countries. A market with little or no restrictions on international transactions will offer foreign investors more possibility of benefiting from geographical and comparative advantages.

Domestic investment is one of the most important factors supporting continuous economic growth in Mexico since the liberalization policy. This is reflected in equations 3.1 to 3.3 where the $K_{p}$ variable is positive and statistically significant in all the equations. The elasticity of output with respect to domestic investment is quantitatively the highest. However, the elasticity of output with respect to FDI is similar to its elasticity

10 Lim (2001) notes that some countries have increased the percentage share of FDI in GDP once they joined a regional trade agreement. For example, in the case of Mexico, it increased this indicator from 1.2 to 2.88 after joining NAFTA, while Argentina and Brazil increased their shares from 1.41 to 2.41 and from 0.32 to 2.17 , respectively, after joining MERCOSUR. 
to the labor force, indicating that Mexico's performance is in accordance with what is expected from an open economy.

We also examine whether the impact of FDI on growth depends on the level of human capital (proxied by the proportion of the population enrolled as students in secondary schools), and as a result test Borensztein et al's (1998) hypothesis that low levels of human capital have negative implications for attracting FDI. For Mexico, we found that the level of human capital had indeed improved the FDI-growth relationship (see positive coefficients in equations 3.1 to 3.6). The efficiency with which the stock of technical knowledge is being absorbed by the host country, via the higher education system is improving particularly with the reforms. In other words, the level of human capital in Mexico has reached the threshold that allows exploiting the technological spillovers associated with FDI.

The positive and statistically significant effect of government consumption as revealed in equations 3.4 to 3.6 contradicts the crowding-out effect predicted by the neoclassical growth model. This is an indication that the Mexican government still plays a relevant role in the development process and more public investment is conducive to improving the effects of FDI on growth. Indeed, part of government spending was used to build infrastructure and institutions to attract foreign investment. The coefficient of the budget balance to GDP has a positive sign and is significant. Although its effect is relatively low compared to the other variables, the results indicate that the influence of FDI on output depends positively on healthy public finances. Since 1988, the government has applied instruments of fiscal policy as a measure to reduce the public deficit which reached 4.4\% of GDP in 1987. Since then the average fiscal deficit has decreased, in part as a result of privatization of public enterprises in the 1980s and as a commitment to meeting some of the IMF's conditions for external debt restructuring.

The ECM terms are negative and significant in all equations and the relative fit and efficiency of the regressions conform with theoretical predictions. The ECM coefficient in equations 3.1 to 3.6 has the right sign and is highly significant. The results from equation 3.6 revealed that deviations from long-run growth in this period are corrected by 34 percent in the following year.

Finally, the coefficient of financial development $\left(f_{n}\right)$ measures how the level of financial development in Mexico influences the growth-FDI relationship. As expected, our results show a significant positive sign in all the regressions. In other words, FDI inflows -given a well developed financial system -have produced positive growth effects on the Mexican economy. It is clear that the monetary policy strategies introduced by the government since the last economic crisis in 1994 have paid off. For a decade, the Bank 
of Mexico has considerably reduced the level of inflation by restricting the growth of the money supply. In 2004, the inflation rate reached its lowest level of 4.3 percent compared with an average of 38 percent until the early 1990s. It is obvious that money and price growth are important indications of financial stability and are taken into consideration by profit-seeking foreign investors.

Due to the current world financial crisis, it is important to reconsider whether it is still appropriate to have an outward-oriented policy as a strategy for growth. Being part of a global market also implies more dependency on other countries' macroeconomic health, especially the U.S. economy. Until 2007, the value of exports represented 35 percent of GDP in Mexico. On the other hand, FDI flows have been increasing since NAFTA, although they still represent less than 3 percent of GDP (Dussel, 2000a). Manufactures accounted for 80 percent of total exports, and 44 percent of them were from maquiladoras. At the end of 2008, the U.S. recession affected manufactures production by reducing its growth rate. This situation reduced manufacturing exports and foreign capital flows, the consequences in some of Mexico's relevant macroeconomic variables have already been predicted. For example, the economic crisis will lead to a reduction in the current account, pressure to increase the exchange rate, inflation and inevitably jobs losses (Ramirez, 2009). Although this study has shown that in a period of relative stability more exports and FDI improve economic growth, the current crisis also shows that it may be a good opportunity to consider if depending on an outward-oriented strategy is the best choice. It may be the right time to stimulate other sectors that have remained neglected, such as domestic industries oriented to satisfying the internal market, the agriculture sector and services. In other words, this could be the opportunity to encourage activities that have strong links to the domestic economy and potential spillover effects.

\section{Conclusions}

The paper examined causal relationships among factors affecting economic growth in Mexico, including the formal investigation of the export-led and FDI-led growth hypotheses. The purpose was to find out if there has been any real benefit from FDI and export promotion favoured by the economic policies of the last two decades. Our review of the literature and our findings suggest that, by and large, foreign direct investment leads to economic growth. The effect, however, varies over time. Our results indicate that domestic investment and openness to international trade are com-

plementary to economic growth. This proves the hypothesis that in an open economy, economic growth is driven largely by domestic investment growth, as would be expected, and also by foreign investment. Controlling for domestic investment growth 
as well as other factors, causality tests show support for the export-led growth and FDI-led growth hypotheses.

The paper finds that the key factors affecting economic growth in Mexico are FDI, domestic investment, exports, human capital and, to a lesser extent, the ratio of government consumption and budget balance to GDP, and financial depth. It is worth noting, however, that while the impact of FDI on growth is positive, it is still smaller than that of domestic investment. The reason for this is that FDI still concentrates in some industries with low value added, for example the Maquiladora industry or in industries where the links with local suppliers are limited (Dussel, 2000b). Other studies indicate that only where there are similar technological capabilities between foreign and national companies is it more likely that positive spillover effects will be obtained (Dominguez and Brown, 2004). Therefore, subsequent efforts by the Mexican government to promote foreign investment in economic activities where spillover effects are more likely to occur, will definitely improve the influence of FDI on the whole economy. Further, putting the current results in context, our findings attest to Lachler and Aschauer (1998) and Aka (2007). Although, the impact of private investment is slightly higher than that of public investment, they are both conducive to improving the effects of FDI on growth in Mexico. Government spending tailored towards enabling the environment to stimulate growth will also enhance the inflow of FDI into Mexico.

The policy implication of the positive association between exports, FDI and GDP growth reveals that economic reform policies and the shift towards a free market continued to help the economy to reallocate its resources towards productive uses. In other words, to attract more FDI, Mexico has to keep on developing its human capital resources, investing in infrastructure, and introducing reforms to provide incentives to profit-seeking investors. These basic factors will not only enhance the benefits of FDI but will also improve the impact of domestic investment on economic growth. 


\section{References}

Aitken, Brian and Ann E. Harrison, "Do Domestic Firms Benefit from Direct Foreign Investment? Evidence from Venezuela", in American Economic Review, vol. 89, no. 3, Pittsburgh, AEA, June 1999, pp. 605-618.

Aka B.F, "Relative effects of Public and Private Investment on Cote d'Ivoire Economic Performance" in Applied Econometrics and International Development, Vol. 7, núm. 1, 2007.

Akinlo, Antony Enisan, "Foreign Direct Investment and Growth in Nigeria -An Empirical Investigation", in Journal of Policy Modeling, vol. 26, no. 5, Amsterdam, Elsevier, July, 2004, pp. 627-639.

Arroyo Picard, Alberto, "NAFTA in Mexico: Promises, Myths and Realities" in Lessons from NAFTA: the high Cost of Free Trade, Hemispheric Social Alliance, 2003, pp. 5-22.

Balasubramanyam, Vudayagiri N. and Mohammed Salisu, "Export Promotion, Import Substitution and Direct Foreign Investment in Less Developed Countries", in A. Koekkoek and Mennes L., International Trade and Global Development: Essays in Honour of Jagdish Bhagwati, Oxford, Routledge, July, 1991.

Balasubramanyam, Vudayagiri N., Mohammed Salisu, and David Sapsford, "Foreign Direct Investment and Growth in EP and IS Countries", in The Economic Journal, vol. 106, no. 434, London, Blackwell Publishing, 1996, pp. 92-105.

Blomstrom, Magnus, and Hakan Persson, "Foreign Investment and Spillover Efficiency in an Underdeveloped Economy: Evidence from the Mexican Manufacturing Industry", in World Development, vol.11, no. 6, Montreal, Elsevier, June 1983, pp. 493-501.

Blomstrom, Magnus, Robert E. Lipsey and Mario Zejan, "What explains developing country growth?", Working Paper, no. 4132, Cambridge, NBER, December 1994a.

Blomstrom, Magnus, Ari Kokko, and Mario Zejan, "Host country competition, labour skills, and technology transfer by multinationals", in Weltwirtschaftliches Archiv, Vol. 130, no. 3, Gottingen, Institut für Weltwirtschaft, September 1994b, pp. 521-533.

Blomstrom, Magnus and Ari Kokko, "Multinational Corporations and Spillovers", in Journal of Economic Services, Vol. 12, no. 3, London, Blackwell Publishing, July 1998.
Borensztein, Eduardo, Jose De Gregorio and Jong W. Lee. "How Does Foreign Direct Investment Affect Economic Growth in Journal of International Economics, vol. 45, no. 1, Amsterdam, Elsevier, June 1998, pp. 115-135.

Buckley, Peter J., Jeremy Clegg and Chengqi Wang, "The impact of foreign direct investment on the performance of Chinese locally owned firms", in Journal of International Business Studies, Vol. 33, no. 4, December, 2002, Hampshire, Palgrave MacMilla, pp. 637-655.

Carkovic, Maria and Ross Levine, "Does Foreign Direct Investment Accelerate Economic Growth?", Working Paper, Minnesota, University of Minnesota, June, 2002.

De Mello Jr, Reis Luiz, "Foreign direct investment, international knowledge transfers and endogenous growth: time-series evidence" in Oxford Economic Papers, Oxford, June, 1999, pp. 133-151.

De Mello Jr, Reis Luiz, "Foreign direct investment in developing countries and growth: a selective survey", in The Journal of Development Studies, vol. 34, no. 1, Amsterdam, Elsevier, October, 1997, pp.1-34.

Dickey, David A., and Wayne A. Fuller, "Likelihood Ratio Statistics for Autoregressive Time-series with a Unit Root", in Econometrica, vol. 49, no. 4, Princeton, Wiley, June, 1981, pp. 1057-1072.

Dimelis, Sophia P., "Spillovers from foreign direct investment and firm growth: Technological, financial and market structure effects", in International Journal of the Economics of Business, vol. 12, no. 1, London, Taylor and Francis, February, 2005, pp. 85-104.

Domínguez Lilia and Flow Brown, "Inversión Extranjera Directa y Capacidades Tecnológicas", CEPAL, Santiago de Chile, United Nations, 2004.

Dussel Peters, Enrique, "La Inversión Extranjera en México", Series 80, CEPAL, Santiago de Chile, United Nations, 2000a.

, Polarizing Mexico: The Impact of Liberalization Strategy, London, Rienner, 2000b.

Elias, Victor Jorge, Sources of Growth: A Study of Seven Latin American Economies, San Francisco, ICS Press, 1992

Easterly, W. Rodriguez, C.A and K SchmidtHabbel (eds), "Public Sector Deficits and Macroeconomic Performance", World Bank and Oxford University Press, Washington DC, 1994.

Vol. 40, núm. 158, julio-septiembre / 2009 
Greenaway, David, David Sapsford and Stephan Pfaffenzeller, "Foreign Direct Investment, Economic Performance and Trade Liberalisation", in The World Economy, vol. 30, no. 2, London Blackwell Publishing, February, 2007, pp. 197-210.

Haddad, Mona and Ann Harrison, "Are there positive spillovers from direct foreign investment? Evidence from panel data for Morocco", in Journal of Development Economics, vol. 42, no. 1, Amsterdam, Elsevier, October 1993, pp. 51-74.

Hsiao, Cheng, "Autoregressive Modelling and Money-Income Causality Detection", in Journal of Monetary Economics, vol. 7, no. 1, Amsterdam, Elsevier, 1981, pp. 85-106.

Ito, Takatoshi, "Capital Flows in Asia", Working Paper, no. 7134, Cambridge, NBER, May, 1999.

Johansen, S and Juselius, K., "Maximum Likelihood Estimation and Inference on Co-integration with Application for the Demand for Money", in Oxford Bulletin of Economics and Statistics, vol. 52, no. 2, Oxford, Wiley, May, 1990, pp. 169-210.

Khan, M.S and M.S Kumar, "Public and Private Investment and the Growth process in Developing Countries" in Oxford Bulletin of Economics and Statistics, Vol. 59, no. 1, 1997, pp. 69-88.

Lachler, U. and D. A. Aschauer, "Public Investment and Economic Growth in Mexico", International Monetary Fund, Policy Research Working Paper, Washigton, D.C., 1998.

Li, Xiaoying and Xiaming Liu, "Foreign Direct Investment and Economic Growth: An Increasingly Endogenous Relationship", in World Development, vol. 33, no. 3, Montreal, Elsevier, March, 2005, pp. 393-407.

Love, J. H. and Francisco Lage-Hidalgo, "Analysing the Determinant of US Direct Investment in Mexico", in Journal of Applied Economics, vol.32, no. 10, Buenos Aires, John Wiley \& Sons, August, 2000, pp. 1259-67.

MacKinnon, James G., "Numerical distribution functions for unit root and co-integration tests", in Journal of Applied Econometrics, vol. 11, no. 6, Cambridge, John Wiley \& Sons, Nov-Dec., 1996, pp. 601-618.

Marwah, K. and L. R. Klein, "What are some Prospects for India's joining the Asian Growth Process?" in Hooley, R. et al. (eds.), Asia Pacific Economic Cooperation: Theory and Practice, Research in Asian Economic Studies, vol. 7, Ottawa, JAI
Press, 1996, pp. 419-439.

Nunnenkamp and Bremont, "FDI in Mexico: An Empirical Assessment of Employment Effects", Kiel Working paper No. 1328, 2007.

Phillips, Peter C. B. and Pierre Perron, "Testing for a Unit Root in Time-series Regression", in Biometrika, vol. 75, no. 2, Oxford, Oxford University Press, 1988, pp. 335346.

Ramirez, Miguel D., "Foreign Direct Investment in Mexico: A Co-integration Analysis", in The Journal of Development Studies, vol. 37, no. 1, London, Routledge, October, 2000, pp.138-162.

Ramírez Sánchez, José de Jesús, "Impacto de la Crisis Internacional en la Economía Mexicana" in Revista Economía Informa, no. 358, Mexico City, May-June, 2009, pp. 64-74.

Romer, Paul Michael, "Idea gaps and object gaps in economic development", in Journal of Monetary Economics, vol. 32, no. 3, Amsterdam, Elsevier, December, 1993, pp. 543-573.

Ros, Jaime, La Desaceleración del Crecimiento Económico en México desde 1982 in El Trimestre Económico, vol. LXXV, no. 3, Mexico, FCE, July-September, 2008, pp. 537-560.

Schneider, Martin, Rui Albuquerque and Gregory H. Bauer, "International Equity Flows and Returns: A Quantitative Equilibrium Approach", Discussion Papers, no. 5159, London, CEPR, 2005.

Sjöholm, F., "Technology Gap, Competition and Spillovers from Direct Foreign Investment: Evidence from Establishment Data", in Journal of Development Studies, vol. 36, no. 1, London, Taylor \& Francis, 1999, pp. 53-73.

Sun, Haishun, "Macroeconomic Impact of Direct Foreign Investment in China: 197996", in The World Economy, vol. 21, no. 5, London, Blackwell Publishing, July, 1998, pp. 675-694.

United Nations Conference on Trade and Development, World Investment Report United Nations, Geneva, UNCTAD, 2006.

Vamvakidis, Athanasious, "Regional Trade Agreements or Broad Liberalization: Which Path Leads to Faster Growth?", IMF Staff Papers, vol. 46, no. 1, Washington, Palgrave Macmillan Journals, March, 1999.

Zhao, H. "Technology Imports and Their Impacts on the Enhancement of China's Technological Capability", in The Journal of Development Studies, vol. 31, London, Taylor \& Francis, April, 1995, pp. 585-602. 


\section{Appendix}

\begin{tabular}{|c|c|c|}
\hline Series & Source & Observations \\
\hline "Y: Gross Domestic Product" & 1/ & $\begin{array}{l}\text { "The series was deflated by the implicit price index, 1993=100 and then } \\
\text { converted to US dollars." }\end{array}$ \\
\hline "Kf: Stock of foreign direct investment" & $3 /$ & $\begin{array}{l}\text { "The series was deflated by an implicit price index. The stock of FDI was } \\
\text { obtained through the perpetual inventory model of the form: } K_{t}=K_{t-1}+\text { It } \\
\text { - } \delta K_{t-1} \text { where } K_{t-1} \text { is the stock of capital at time } t-1 . \text { This is the flow of } \\
\text { gross investment during period }{ }_{t} \text { and } \delta \text { is the rate at which private and } \\
\text { foreign capital depreciates in period } t+-1 \text {. In this research, an initial stock } \\
\text { of } 8 \text { years and } 5 \% \text { depreciation were considered in the calculations." }\end{array}$ \\
\hline "K $K_{p}$ Stock of private capital" & $2 /$ & The series was deflated by an implicit price index. \\
\hline X: Exports & $3 /$ & $\begin{array}{l}\text { "Export goods without crude oil (flows). It was deflated by an export } \\
\text { price index, 1993=100." }\end{array}$ \\
\hline "H: Human Capital" & $4 /, 5 /$ & $\begin{array}{l}\text { "Students enrolled in secondary school. Series was interpolated from } \\
\text { annual to quarterly data." }\end{array}$ \\
\hline L: Labour & 1/ & $\begin{array}{l}\text { "Remunerated workers (economically active labour force). The series } \\
\text { was interpolated from annual to quarterly data." }\end{array}$ \\
\hline "Cg: Government consumption" & l/ & $\begin{array}{l}\text { "The original series was in real terms; it was converted to US dollars and } \\
\text { was seasonally adjusted." }\end{array}$ \\
\hline$F_{n}$ : Financial depth & $1 /, 3 /, 6 /$ & $\begin{array}{l}\text { "This series is a ratio between broad money taken as MI divided by } \\
\text { GDP. The series were in current prices." }\end{array}$ \\
\hline$B_{g}:$ Budget balance & $1 /, 3 /$ & $\begin{array}{l}\text { "This series is the ratio between budget balance divided by GDP. Both } \\
\text { series were taken in real terms." }\end{array}$ \\
\hline
\end{tabular}

\section{Sources}

"1/ Instituto Nacional de Estadistica Geografia e Informatica (INEGI), IMF and World Bank.

2/IMF and World Bank.

3/ Indicadores Económicos y Financieros, Banco de México, IMF and World Bank.

4/ Estadísticas Históricas de México, Volumes I and II, 1999. INEGI, IMF and World Bank.

5/ Estadísticas de la Educación, 2002 edition. INEGI, IMF and World Bank.

6/ Informe Anual (various issues), Banco de México; IMF and World Bank. ."

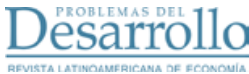

